\title{
KARAKTERISTIK AKAR BEREKTOMIKORIZA PADA Shorea pinanga, Pinus merkusii DAN Gnetum gnemon
}

\author{
Root Characteristics of Ectomycorrhizal Fungi on Shorea pinanga, Pinus merkusii, and Gnetum gnemon
}

Melya Riniarti, Irdika Mansur, Arum Sekar Wulandari, dan Cecep Kusmana

\begin{abstract}
Morphology and anatomy characteristics often used to identify ectomycorrhizal fungi. We used three Scleroderma spp. (Scleroderma columnare, S. dictyosporum), and S. sinnamariense) and inoculated to Shorea pinanga, Pinus merkusii, and Gnetum gnemon. After 6,8, and 10 months, each root tips were collected to determined hyphae colour, branching pattern, clamp-connection, hartig net and mantle. This result revealed that $S$. sinnamariense did not form association with $S$. pinanga and $P$. merkusii but form association with $G$. gnemon. On the other hand, S. columnare and S. dictyosporum could form association with all the host plants. $S$. columnare and $S$. dictyosporum formed white hyphae while $S$. sinnamariense formed yellow hyphae with monopodial branching pattern. The depth of hartig net and mantle was increased by timed.
\end{abstract}

Key words: ectomycorrhizal fungi, hartig net, mantle, Scleroderma

\section{PENDAHULUAN}

Ektomikoriza merupakan simbiosis mutualisme antara fungi dan akar tanaman, dalam hubungan ini fungi memperoleh hasil fotosintesis sementara akar mendapat bantuan unsur hara dan air dan keuntungan lainnya melalui perantara hifa fungi (Allen et al. 2003; Dehlin et al. 2004). Sebagian besar tanaman yang membentuk simbiosis dengan fungi ektomikoriza adalah jenis pohon, sekalipun beberapa jenis semak dan perdu juga ditemukan dapat berasosiasi dengan fungi ini (Onguene dan Kuyper 2002). Fungi ektomikoriza diketahui dapat berasosiasi dengan jenis-jenis tanaman dari family Dipterocarpaceae (Turjaman et al. 2005, Turjaman et al. 2006), Pinaceae (Chen 2006, Linda 2006) dan Gnetaceae (Wulandari 2002; Watling et al. 2002), yang merupakan bagian dari angiospermae dan gymnospermae.

Hubungan fungi dengan tanaman inang ini dapat disebut ektomikoriza bila terdapat beberapa karakteristik morfologi dan anatomi pada akar tanaman akibat masuknya hifa pada sel-sel akar. Terdapat berbagai variasi dalam karakteristik morfologi dan struktur akar berektomikoriza, namun terdapat tiga bentuk utama yang secara umum disepakati sebagai karakteristik penting, yaitu terbentuknya sebuah mantel atau lapisan hifa dan miselium fungi yang menutupi sebagian dari ujung akar, berkembangnya hifa di antara sel-sel akar yang membentuk sel-sel yang kompleks yang disebut hartig net, dan hifa-hifa yang menonjol keluar dari mantel dan berkembang ke tanah (hifa ekstra radikal) (Petterson et al. 2004). Bahkan menurut Smith dan Read (2008) bila salah satu dari tiga ciri utama ini tidak terbentuk dengan sempurna maka peranan fungi ektomikoriza pada tanaman inang tidak akan berjalan dengan baik.

Masing-masing fungi ektomikoriza akan memiliki karakteristik morfologi dan anatomi yang khas pada tanaman inang yang diinfeksinya. Keunikan ini menjadi ciri yang akan digunakan untuk mengidentifikasi dan mengklasifikasikan jenis-jenis fungi tersebut (Agerer 2002), sehingga akan lebih meningkatkan pemahaman akan fungsi dan mekanisme yang terjadi antara fungi dan tanaman inangnya.

Tujuan penelitian ini adalah memperoleh informasi tentang karakteristik morfologi dan anatomi akar pada Shorea pinanga, Pinus merkusii, dan Gnetum gnemon yang telah diinokulasi dengan tiga jenis Scleroderma spp. selama 6,8 dan 10 bulan. 


\section{BAHAN DAN METODE}

\section{Bahan Tanaman}

Akar S. pinanga, P. merkusii dan G. gnemon (berumur 6, 8, dan 10 bulan setelah inokulasi) dicuci perlahan dan hati-hati di bawah air mengalir untuk melepaskan partikel-partikel tanah yang menempel. Akar-akar tersebut kemudian diamati di bawah mikroskop, dan dipilih yang memiliki ciriciri akar yang terinfeksi fungi ektomikoriza, yaitu cenderung lebih pendek dan memiliki diameter lebih besar, serta diselubungi oleh lapisan hifa. Akar-akar tersebut kemudian direndam dalam larutan FAA (Formaldehyde acetic acid) selama 24 jam untuk proses analisis lebih lanjut.

\section{Analisis Histologi}

Penyiapan preparat untuk pengamatan anatomi akar dilakukan dengan metode Sass (1958). Metode ini dimulai dengan fiksasi akar menggunakan FAA selama 24 jam, lalu diteruskan dengan proses dehidrasi, yaitu upaya pengeluaran air dari dalam jaringan tanaman, proses ini menggunakan alkohol. Proses selanjutnya adalah praparafinasi, yang bertujuan menghilangkan alkohol dari jaringan tanaman agar dapat diisi dengan parafin, proses ini menggunakan alkohol $100 \%$ dan xylol dengan beberapa tahapan. Proses parafinasi dilakukan menggunakan xylol dan parafin dengan konsentrasi berbeda-beda dengan empat tahapan dan selama 24 jam, dalam oven dengan suhu $55^{\circ} \mathrm{C}$.

Hasil parafinasi kemudian dicetak dan hasilnya dipotong menggunakan mikrotom dengan ukuran $5-10 \mu \mathrm{m}$, dan dilanjutkan pada tahapan pewarnaan akar. Teknik pewarnaan akar dilakukan dalam 19 tahapan. Pewarna yang digunakan adalah safranin 0,5\% dan alcian blue $1 \%$. Setelah keseluruhan proses ini dilakukan maka preparat akar dapat diamati di bawah mikroskop untuk melihat anatomi akar.

\section{Parameter yang Diamati}

Pengamatan dilakukan pada morfologi dan anatomi akar berektomikoriza. Tipe morfologi yang diamati adalah warna miselium, bentuk percabangan, dan clamp-connection. Pengamatan anatomi akar dilakukan dengan mengamati diameter akar, bentuk dan ketebalan mantel, ketebalan dan jumlah mantel, serta kedalaman hartig net. Pengamatan dilakukan pada setiap akar S. pinanga, P. merkusii, dan G. gnemon yang terinfeksi fungi ektomikoriza pada tiga bulan pengamatan ( 6,8 dan 10 bulan).

\section{HASIL DAN PEMBAHASAN}

\section{Hasil}

\section{Karakteristik akar berektomikoriza pada $P$. merkusii}

S. columnare dan $S$. dictyosporum dapat membentuk ektomikoriza dengan akar $P$. merkusii. Kedua jenis fungi ektomikoriza memiliki hifa dan miselium berwarna putih, dan dengan percabangan monopodial (Gambar 1). Hifa eksternal yang terbentuk dari $S$. columnare memiliki septa dan tidak memiliki clampconnection, sedangkan hifa dari S. dictyosporum memiliki septa dan membentuk clamp-connection.

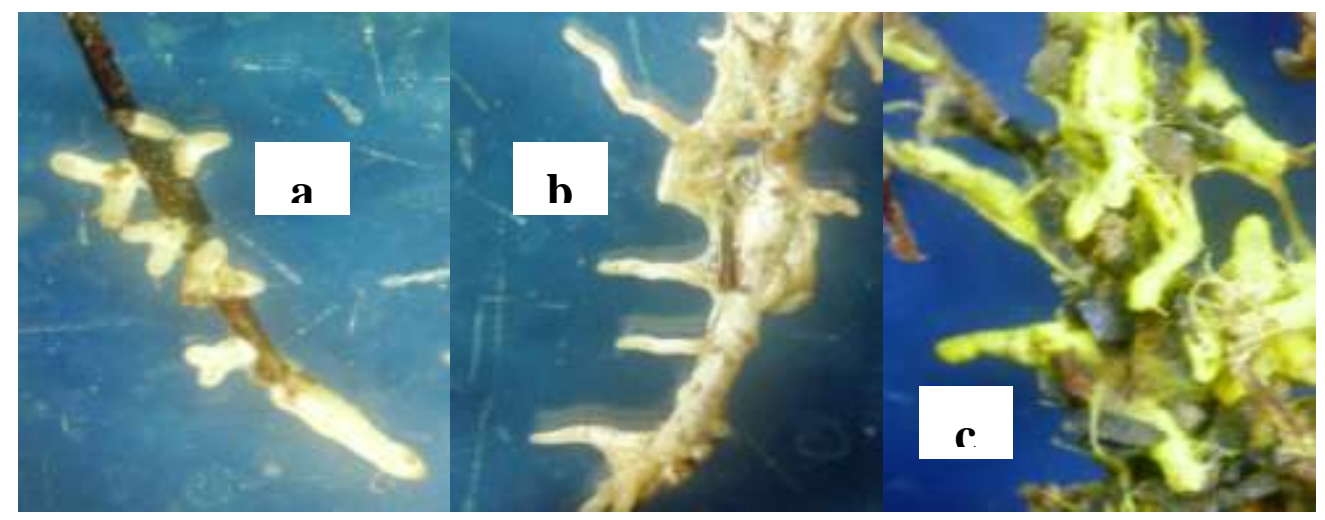

Figure 1 Ectomycorrhizal root tip (10x3): (a) S. dictyosporum on P. Merkusii, (b) S. columnare on $S$. Pinanga, and (c) S. sinnamariense on G. gnemon. 
Table 1. Mean value of root histology of $P$. merkusii inoculated with $S$. columnare and $S$. dictyosporum after 6,8 , dan 10 months of inoculation

\begin{tabular}{lrcccc}
\hline Treatments & Months & $\begin{array}{c}\text { Hartig net } \\
\text { thickness } \\
(\mu \mathrm{m})\end{array}$ & $\begin{array}{c}\text { Mantle } \\
\text { thickness } \\
(\mu \mathrm{m})\end{array}$ & $\begin{array}{c}\text { Number of } \\
\text { mantle }\end{array}$ & $\begin{array}{c}\text { rof root } \\
(\mu \mathrm{m})\end{array}$ \\
\hline S. columnare & 6 & 53,75 & 9,38 & 1 & 156,93 \\
S. dictyosporum & 6 & 75,25 & 13,75 & 1 & 202,76 \\
S. columnare & 8 & 79,38 & 21,25 & 1 & 229,14 \\
S. dictyosporum & 8 & 88,13 & 28,13 & 2 & 212,48 \\
S. columnare & 10 & 68,75 & 19,38 & 1 & 163,87 \\
S. dictyosporum & 10 & 82,88 & 25,00 & 2 & 162,48 \\
\hline
\end{tabular}

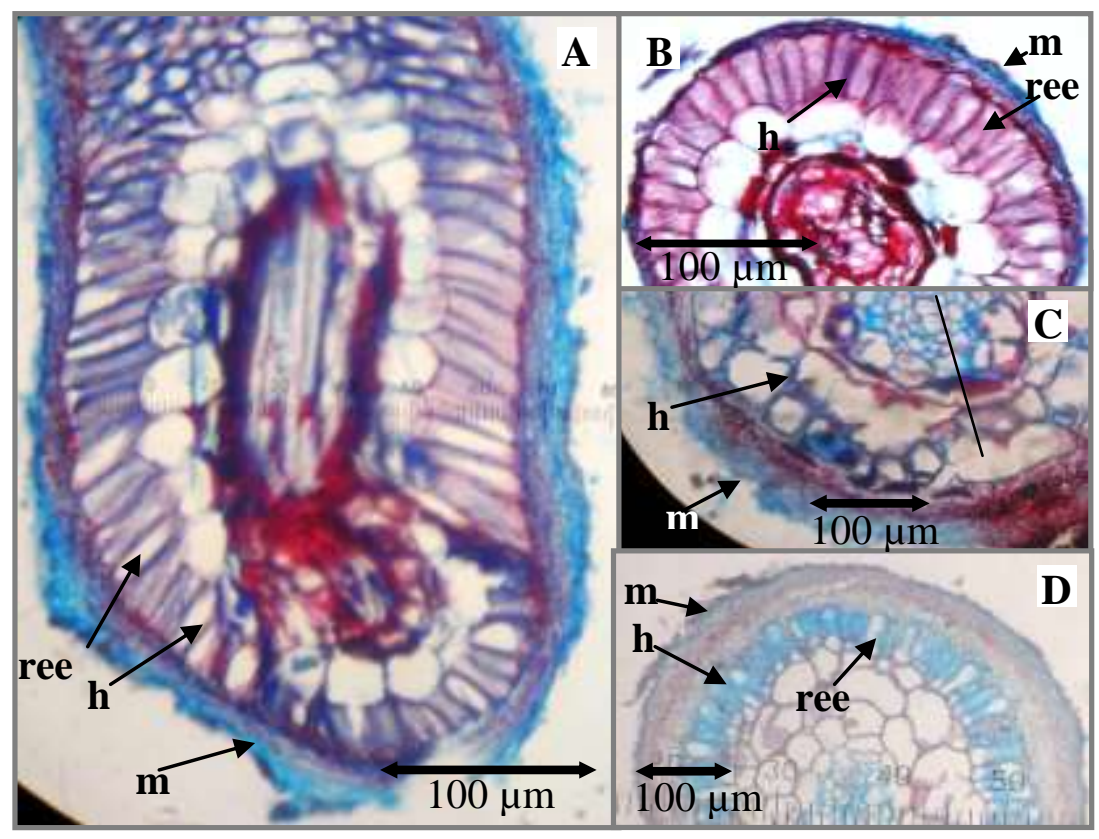

Figure 2. Ectomycorrhizal root: left side (A) longitudinal section of $S$. pinanga root (mag. 10x40); right side (B) transverse section of $S$. pinanga (mag. 10x40), (C) P. merkusii root (mag. 10x40), (D) G. gnemon root (mag. 10x10); (h) hartig net, (m) mantle, (ree) radial elongation epidermis.

Nilai rata-rata jari-jari akar berektomikoriza yang terbentuk dengan $S$. columnare berkisar 156-229 $\mu \mathrm{m}$, sementara akar yang terbentuk dengan S. dictyosporum memiliki kisaran 162$202 \mu \mathrm{m}$ (Tabel 1). Kedalaman hartig net dan ketebalan mantel juga meningkat setiap bulan pengamatan pada kedua fungi, namun $S$. dictyosporum cenderung memiliki nilai rata-rata yang lebih tinggi dibandingkan dengan $S$. columnare. Pada tanaman ini hartig net terbentuk hingga ke lapisan korteks (Gambar 2). Komposisi pembuluh akar, hartig net dan mantel disajikan pada Gambar (3). Hartig net dan mantel yang terbentuk semakin dalam dan tebal seiring dengan meningkatnya waktu baik oleh $S$. columnare maupun pada $S$. dictyosporum. S. dictyosporum tampaknya memiliki kompatibilitas yang lebih baik dengan $P$. merkusii dibandingkan dengan $S$. columnare. 


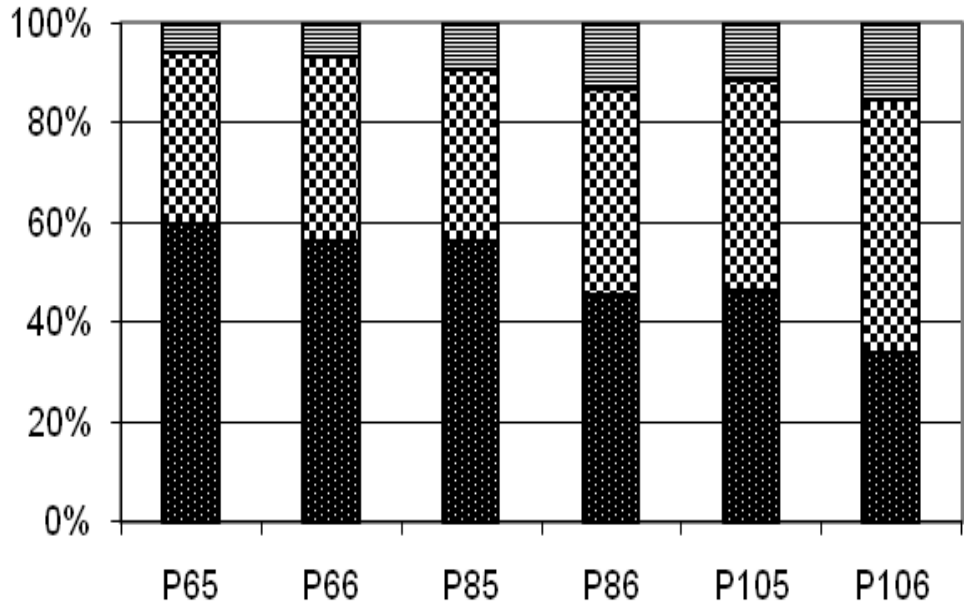

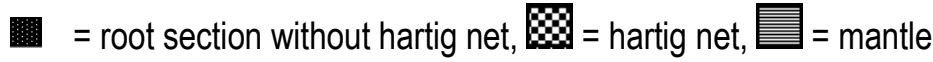
Remarks: P65
S. columnare umur 6 bulan
P86
S. dictyosporum umur 8 bulan
P66
S. dictyosporum umur 6 bulan
$\mathrm{P} 105$
S. columnare umur 10 bulan
P85
S. columnare umur 8 bulan
P106
S. dictyosporum umur 10 bulan

Figure 3. Composition of root section without hartig net, root section with hartig net, and mantle of $P$. merkusii ectomycorrhizal root inoculated with $S$. columnare and $S$. dyctosporum after 6,8 , and 10 months inoculation.

\section{Karakteristik akar berektomikoriza pada S. pinanga}

Pada S. pinanga, hanya S. columnare dan S. dictyosporum yang membentuk ektomikoriza. Dan seperti pada $P$. merkusii, kedua fungi ini memiliki hifa berwarna putih dan memiliki percabangan monopodial (Gambar 1). Hifa S. columnare memiliki septa dan tidak membentuk clampconnection. Sementara hifa dari S. dictyosporum memiliki septa dan membentuk clamp-connection.
Berbeda dengan P. merkusii, hartig net dan mantel yang terbentuk pada $S$. pinanga hanya terbentuk pada lapisan epidermis dan cenderung lebih dalam dan tebal di bulan ke enam, dan menurun pada bulan ke delapan dan ke sepuluh (Tabel 2 dan Gambar 4). Hartig net dan mantel yang dibentuk oleh $S$. columnare juga cenderung lebih dalam dan tebal dibandingkan yang dibentuk oleh S. dictyosporum.

Table 2. Mean value of root histology of $S$. pinanga inoculated with S. columnare and S. dictyosporum after 6,8 , dan 10 months of inoculation

\begin{tabular}{lccccc}
\hline \multicolumn{1}{c}{ Treatments } & Months & $\begin{array}{c}\text { Hartig net } \\
\text { thickness }(\mu \mathrm{m})\end{array}$ & $\begin{array}{c}\text { Mantle thickness } \\
(\mu \mathrm{m})\end{array}$ & $\begin{array}{c}\text { Number of } \\
\text { mantle }\end{array}$ & $\begin{array}{c}r \text { of root } \\
(\mu \mathrm{m})\end{array}$ \\
\hline S. columnare & 6 & 41,25 & 33,75 & 1 & 166,65 \\
S. dictyosporum & 6 & 23,13 & 15,63 & 1 & 105,55 \\
S. columnare & 8 & 18,25 & 16,50 & 1 & 113,88 \\
S. dictyosporum & 8 & 13,75 & 16,88 & 1 & 129,15 \\
S. columnare & 10 & 27,00 & 16,25 & 1 & 99,99 \\
S. dictyosporum & 10 & 11,25 & 13,75 & 1 & 91,66 \\
\hline
\end{tabular}




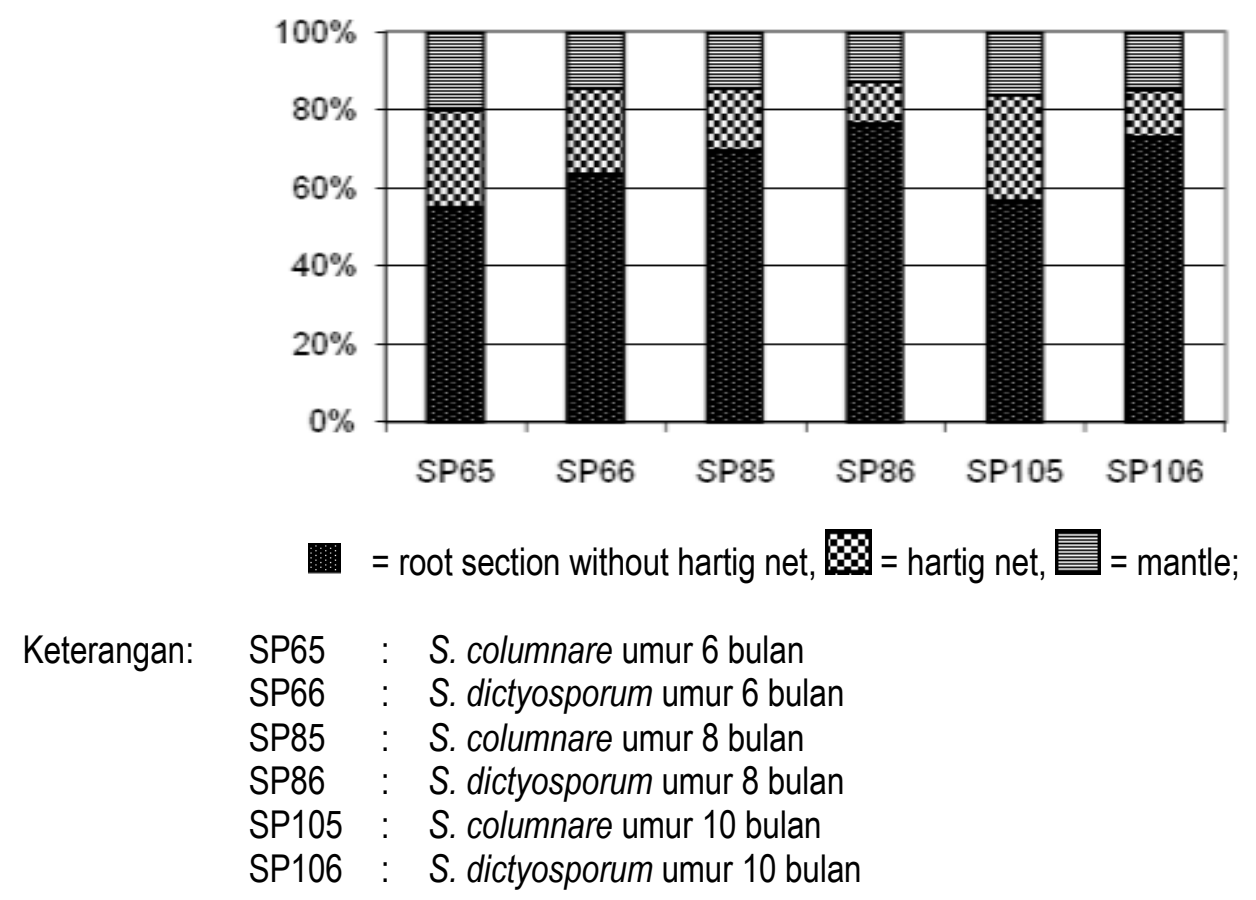

Figure 4. Composition of root section without hartig net, root section with hartig net, and mantle of $P$. pinaga ectomycorrhizal root inoculated with $S$. columnare and $S$. dyctosporum after 6,8 , and 10 months inoculation.

\section{Karakteristik akar berektomikoriza pada G. gnemon}

Ketiga fungi ektomikoriza Scleroderma spp. memiliki kompatibilitas dengan G. gnemon. $S$. columnare dan $S$. dictyosporum memiliki hifa dan miselium berwarna puth dan percabangan monopodial. Hifa yang terbentuk dari $S$. columnare bersepta dan tidak memiliki clamp- connection. Sementara hifa yang terbentuk dari $S$. dictyosporum bersepta dan membentuk clampconnection.

Hifa dan mantel yang terbentuk dari $S$. sinnamariense berwarna kuning, memiliki septa dan membentuk clamp-connection (Gambar 2). Pada G. gnemon, hartig net yang terbentuk dari ketiga jenis fungi hanya ada di lapisan epidermis.

Table 3. Mean value of root histology of $G$. gnemon inoculated with $S$. columnare and $S$. dictyosporum after 6, 8, dan 10 months of inoculation

\begin{tabular}{lccccc}
\hline \multicolumn{1}{c}{ Treatments } & Months & $\begin{array}{c}\text { Hartig net thickness } \\
(\mu \mathrm{m})\end{array}$ & $\begin{array}{c}\text { Mantle thickness } \\
(\mu \mathrm{m})\end{array}$ & $\begin{array}{c}\text { Number of } \\
\text { mantle }\end{array}$ & $\begin{array}{c}r \text { of root } \\
(\mu \mathrm{m})\end{array}$ \\
\hline S. columnare & 6 & 33,33 & 66,66 & 1 & 206,09 \\
S. dictyosporum & 6 & 55,55 & 91,66 & 1 & 301,36 \\
S. sinnamariense & 6 & 61,11 & 50,00 & 1 & 252,75 \\
S. columnare & 8 & 50,00 & 50,00 & 1 & 224,68 \\
S. dictyosporum & 8 & 33,33 & 50,00 & 2 & 158,32 \\
S. sinnamariense & 8 & 38,89 & 76,52 & 2 & 273,59 \\
S. columnare & 10 & 38,89 & 52,77 & 2 & 186,09 \\
S. dictyosporum & 10 & 47,22 & 80,55 & 2 & 185,97 \\
S. sinnamariense & 10 & 33,33 & 47,22 & 2 & 208,25 \\
\hline
\end{tabular}




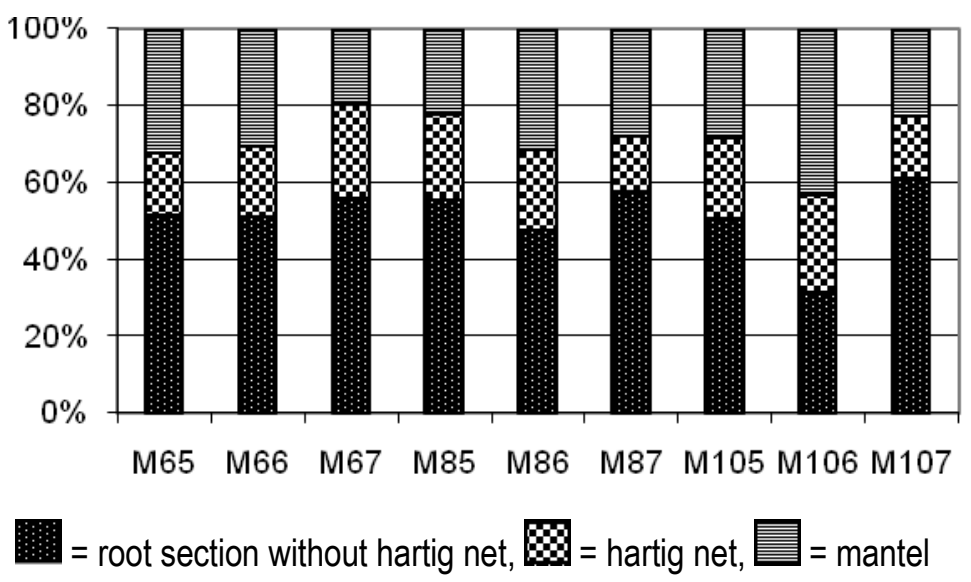

$\begin{array}{rllll}\text { Keterangan: } & \text { M65 } & : \text { S. columnare } 6 \text { bulan } & \text { M87 } & : \text { S. sinnamariense } 8 \text { bulan } \\ & \text { M66 } & : \text { S. dictyosporum } 6 \text { bulan } & \text { M105 }: \text { S. columnare } 10 \text { bulan } \\ \text { M67 } & : \text { S. sinnamariense } 6 \text { bulan } & \text { M106 }: \text { S. dictyosporum } 10 \text { bulan } \\ \text { M85 } & : \text { S. columnare } 8 \text { bulan } & \text { M107 }: \text { S. sinnamariense } 10 \text { bulan } \\ \text { M86 } & : \text { S. dictyosporum } 8 \text { bulan } & & \end{array}$

Figure 5. Composition of root section without hartig net, root section with hartig net, and mantle of $G$. gnemon ectomycorrhizal root inoculated with $S$. columnare and $S$. dyctosporum after 6, 8, and 10 months inoculation.

Nilai rata-rata pengamatan irisan melintang akar dapat dilihat pada Tabel 3 dan Gambar 5). Jari-jari akar, kedalaman hartig net dan ketebalan mantel dari ketiga jenis Scleroderma bervariasi dan tidak membentuk suatu pola tertentu. Walaupun terdapat kecenderungan bahwa kedalaman hartig net yang terbentuk dari $S$. dictyosporum lebih dalam daripada kedua fungi lainnya.

\section{Pembahasan}

Warna miselium merupakan salah satu tipe morfologi penciri dari ektomikoriza (Brundrett et al. 1996) yang dapat dilakukan dengan mata telanjang. Seperti hasil penelitian-penelitian sebelumnya (Santoso 1997; Tata 2001; Wulandari 2002) hifa yang dihasilkan oleh $S$. columnare dan $S$. dictyosporum memiliki ciri yang hampir serupa. Keduanya digambarkan memiliki hifa berwarna putih. Santoso (1997) menyatakan perbedaan antara keduanya dapat dilihat dari halus-kasar permukaan miselium yang terbentuk. Menurutnya, S. columnare memiliki permukaan yang lebih kasar, sementara $S$. dictyosporum tampak lebih halus. Sementara Wulandari (2002) membedakan keduanya dari kekuatan hifa tersebut memegang partikel tanah. Hifa-hifa S. columnare lebih mudah dipisahkan dari partikel tanah yang menempel dibandingkan dengan S. dictyosporum. Selain itu, warna hifa $S$. columnare cenderung tidak berubah akibat proses pencucian maupun perendaman dalam FAA. Sebaliknya, S. dictyosporum hifanya akan kehilangan warna akibat pencucian dan perendaman dalam FAA. Hifa $S$. sinnamariense memiliki ciri khas yang berbeda dari kedua fungi Scleroderma lainnya. Hifa fungi ektomikoriza ini berwarna kuning, warnanya begitu mencolok hingga mudah untuk dipisahkan dengan hifa fungi ektomikoriza lainnya.

Tipe morfologi lain adalah adanya septa dan clamp-connection pada hifa. Menurut Brundrett et al. (1996), sebagian besar fungi ektomikoriza dari family Basidiomycetes memiliki septa dan clampconnection. Hasil ini serupa dengan yang diperoleh Santoso (1997), Tata (2001), Wulandari (2002) dan Prameswari (2005), yang mendapatkan clamp-connection pada hifa yang berasal dari $S$. columnare, S. dictyosporum dan S. sinnamariense. Namun, hasil yang berbeda dihasilkan oleh Chen (2006), yang mengelompokkan Genus Scleroderma menjadi empat yang didasarkan pada perbedaan bentuk spora dan keberadaan clampconnettion. Dalam kategori Chen (2006) tersebut, S. columnare merupakan kelompok Scleroderma 
yang diketahui tidak membentuk clamp-connection, seperti yang dihasilkan pada penelitian ini Namun, hal ini membutuhkan penelitian lebih lanjut.

Keberadaan hartig net merupakan indikator adanya kompatibilitas fungi dan tanaman inang. Pada penelitian ini terlihat bahwa fungi ektomikoriza yang secara alami bersimbiosis dengan masing-masing tanaman inang ( $S$. columnare $-S$. pinanga; $S$. dictyosporum- $P$. merkusii; S. sinnamariense-G. gnemon) cenderung memiliki hartig net yang lebih dalam. Hal ini berkaitan dengan fungsi dari struktur ini. Menurut Petterson et al. (2004), hartig net merupakan tempat pertukaran nutrisi, di mana fungi mengabsorbsi karbohidrat, dan tempat di mana nutrisi dan air menuju sel akar. Bücking dan Heyser (2001) menunjukkan dengan analisis autoradiografi adanya aliran karbohidrat dari sel akar masuk ke dalam hartig net dan kemudian menuju mantel, dan sebaliknya ditemukan juga adanya aliran fosfat dari mantel menuju hartig net lalu ke sel akar.

Pembentukan hartig net dimulai oleh hifa dengan cara memasuki ruang antara sel-sel luar dari pusat akar. Penetrasi ini secara normal dimulai dari mantel yang terdalam. Namun, dapat pula terjadi, hifa akan segera membentuk hartig net dan berkembang bahkan sebelum terbentuk mantel (Smith dan Read 2008). Kedalaman hartig net berbeda antara angiospermae dan gymnospermae (Petterson et al. 2004). Pada sebagian besar angiospermae, kedalaman hartig net hanya pada lapisan epidermis, hingga sering kali disebut sebagai "epidermal hartig nef". Ada dua tipe hartig net pada angiospermae, yaitu (1) "para-epidermal", di mana ada bagian dari epidermis yang tidak ditutupi oleh hartig net dan (2)"peri-epidermal" di mana seluruh epidermis ditutupi oleh hartig net. Kedua tipe ini menunjukkan adanya kemungkinan keberlanjutan pembentukan hartig net yang akan tergantung pada umur akar dan kondisi lingkungan (Smith dan Read 2008). Selain itu, pada angiospermae terbentuk adanya Radial Elongation of Epidermis (REE).

Sementara pada gymnospermae hartig net memiliki penetrasi yang lebih dalam. Hartig net masuk hingga ke beberapa lapisan korteks, hingga disebut sebagai "cortical hartig net". Pada gymnospermae tidak terbentuk REE.
Mantel merupakan pembatas antara akar tanaman dengan tanah. Berbagai penelitian telah dilakukan untuk melihat fungsi dan bentuk mantel yang ada (Agerer dan Raildh 2004; Agerer 2001; Beccera et al. 2005). Mantel berfungsi sebagai tempat penyimpanan berbagai unsur organik dan mineral, mantel juga merupakan tempat penyimpanan unsur-unsur logam berat yang berpotensi menjadi toksik bagi tanaman, sehingga tanaman akan terhindar dari keracunan. Mantel juga melindungi akar dari kehilangan air dan dari serangan patogen (Petterson et al .2004).

Mantel juga banyak digunakan sebagai karakteristik dalam identifikasi dan klasifikasi fungi ektomikoriza. Agerer (2006) mendeskripsikan dua bentuk mantel, bentuk di mana hifa masih dapat dikenali struktur individunya disebut "plectenchymatous atau prosenchymatous" dan bentuk di mana hifa tidak dapat dipisahkan secara individu karena telah membentuk suatu struktur yang kompak disebut "pseudoparenchymatous". Agerer (2006) juga memisahkan sembilan tipe plectenchymatous dan tujuh tipe pseudoparenchymatous. Dalam penelitian ini $S$. dictyosporum dan $S$. sinnamariense dapat membentuk lebih dari satu lapisan mantel pada $P$. merkusii dan G. gnemon, hal ini tampaknya berkaitan dengan kompatibilitas kedua fungi tersebut pada tanaman inang.

\section{DAFTAR PUSTAKA}

Agerer R. 2006. Fungal Relationship and Structural Identity of Their Ectomycorrhiza. Mycol Progress 5:67-107.

2002. Rhizomorph Structure Confirm The Relationship Between Lycoperdales and Agaricaceae. Nova Hedwig 75:367-385.

2001. Exploration Types of Ectomycorrhiza. A Proposal to Classify Ectomycorrhizal Mycelial Systems According to Their Patterns of Differentiation and Putative Ecological Importance. Mycorrhiza 11:107-114.

Agerer R. and Raildh S. 2004. Distance-Related Semi-quantitative Estimation of Extramatrical Ectomycorrhizal Mycelia of Cornarius obtusus. Mycol Progress 3:57-64.

Allen M.F., Swenson W., Querejeta J.J. Warburton L.M.E. and Treseder K.K. 2003. Ecology of 
Mycorrhizae: A Conceptual Framework for Complex Interactions Among Plants and Fungi. Annu. Rev. Phytopathol 41:271-303.

Beccera A. Daniele C. and Nouhra E. 2005. Ectomycorrhiza of Cortinaleus holedes with Alnus acciminta from Argentina. Mycorrhiza 15:7-15.

Brundrett M., Bougher N., Dell B., Grove T. and Malajezuk N. 1996. Working with Mycorrhiza in Forestry and Agriculture. Canberra: Australian Centre for International Agricultural Research.

Bücking H. and Heyser W. 2001. Microradiographic localization of phosphate and carbohydrates in mycorrhizal roots of Populus tremula $\times$ Populus alba and the implications for transfer processes in ectomycorrhizal associations. Tree Physiol 21:101-107.

Chen Y. 2006. Optimizing Scleroderma Spore Inoculum for Eucalyptus Nursery in South China [Disertasi]. Perth: Division of Biology and Engineering, Murdoch University.

Dehlin H., Nilson M.C., Wardle D.A. and Shevtsova. 2004. Effect of Shading and Humus Fertility on Growth, Competition and Ectomycorrhizal Colonization of Boreal Forest Tree Seedling. Can. J. For. Res 34:25732586.

Linda S. 2006. Variation of Ectomycorrizal Community in High Mountain Norway Spruce Stands and Correlation with the Main Climatic Factor [Disertasi]. Munchen: Departemen Biologi, Universitas Degli Dipa Di Palopa.

Onguene NA. and Kuyper TW. 2002. Importance of Ectomycorrhiza Network for Seedling Survival and Ectomycorrhiza Formation in Rain Forests of South Cameroon. Mycorrhiza 12:13-17.

Petterson R.L., Massicotte H.B. and Melville L.H. 2004. Mycorrhiza: Anatomy and Cell Biology. Ottawa. NRC Research Press.

Prameswari D. 2005. Aplikasi Beberapa Cendawan Ektomikoriza untuk Meningkatkan
Pertumbuhan Semai Shorea selanica. J Hut Trop 1:13-18.

Santoso E. 1997. Hubungan Perkembangan Ektomikoriza dengan Populasi Jasad Renik dalam Rhizosfer dan Pengaruhnya Terhadap Pertumbuhan Eucalytus pellita dan Eucalyptus urophylla [Disertasi]. Bogor: Program Pascasarjana, Institut Pertanian Bogor.

Sass, J.E. 1958. Botanical Microtechnique. Third Edition. lowa State Univ. Press. USA.

Smith, S.E. and Read D.J. 2008. Mycorrhizal Symbiosis. Third Edition. London: Academic Press.

Tata M.H.L. 2001. Pengaruh Kebakaran Hutan Terhadap Daya Tahan Hidup Fungi Ektomikoriza Dipterocarpaceae [Thesis]. Bogor: Program Pascasarjana, Institut Pertanian Bogor.

Turjaman M., Tamai Y., Segah H., Limin S.H., Cha J.Y., Osaki M., and Tawaraya K. 2005. Inoculation with the Ectomycorrhizal Fungi Pisolithus arhizus and Scleroderma sp. Improves Early Growth of Shorea pinanga nursery seedlings. New Forest 30:67-73.

Turjaman M., Tamai Y., Segah H., Limin S.H., Osaki M., and Tawaraya K. 2006. Increase in Early Growth and Nutrient Uptake of Shorea seminis Seedlings Inoculated with Two Ectomycorrhizal Fungi. $J$ of Trop For Sci 18:243-249.

Watling R., Lee S.S. and Turnbull E. 2002. The Occurrence and Distribution of Putative Ectomycorrhizal Basidiomycetes in a Regenerating South East Asian Rain Forest. Di Dalam: Watling R, Frankland JC, Ainsworth AM, Isaac $\mathrm{S}$, Robinson $\mathrm{CH}$, editor. Tropical Mycology Volume 1, Macromycetes. New York: CABI Publishing.

Wulandari A.S. 2002. Beberapa Gatra Biologi Ektomikoriza Scleroderma pada Melinjo [Disertasi]. Bogor: Program Pascasarjana, Institut Pertanian Bogor. 
Diterima : 20 Nopember 2009

\author{
Melya Riniarti \\ Jurusan Kehutanan, Fakultas Pertanian \\ Universitas Lampung. JI Sumantri Brojonegoro No 1 \\ Gd. Meneng Bandar Lampung 35145. \\ e-mail: m_riniarti@yahoo.com \\ Irdika Mansur, Arum Sekar Wulandari, dan Cecep Kusmana \\ Departemen Silvikultur, Fakultas Kehutanan \\ Institut Pertanian Bogor. \\ JI. Lingkar Akademik Kampus IPB Darmaga 16680
}

